Article

\title{
Prevalence and Risk Factors of Internet Addiction among Hungarian High School Teachers
}

\author{
Gábor Tóth ${ }^{1,2,+}$, Krisztian Kapus ${ }^{1, \dagger}{ }^{\dagger}$ David Hesszenberger ${ }^{3}$, Marietta Pohl ${ }^{1}$, Gábor Kósa ${ }^{1}$, Julianna Kiss ${ }^{1}$, \\ Gabriella Pusch ${ }^{4}$, Éva Fejes ${ }^{1,5}$, Antal Tibold ${ }^{1}$ and Gergely Feher ${ }^{1,6, *}$ \\ 1 Centre for Occupational Medicine, Medical School, University of Pécs, 7624 Pécs, Hungary; \\ titkarsag@bajakorhaz.hu (G.T.); kapus.krisztian@kozut.hu (K.K.); pohlmarietta@bmvk.hu (M.P.); \\ kosagabor@kosagabor.hu (G.K.); julianna.kiss@shl.hu (J.K.); titkarsag@komloikorhaz.hu (É.F.); \\ tibold.antal@pte.hu (A.T.) \\ 2 Szent Rókus Hospital, 6500 Baja, Hungary \\ 3 Department of Laboratory Medicine, Medical School, University of Pecs, 7624 Pécs, Hungary; \\ david.hesszenberger@aok.pte.hu \\ 4 Department of Neurology, Medical School, University of Pecs, 7624 Pécs, Hungary; fmk@pte.hu \\ 5 Hospital of Komlo, 7300 Komlo, Hungary \\ 6 Neurology Outpatient Clinic, EÜ-MED KFT, 7300 Komló, Hungary \\ * Correspondence: feher.gergely@pte.hu; Tel.: +36-72/518-523; Fax: +36-72/518-521 \\ + G.T. and K.K. are equally contributed to this manuscript.
}

Citation: Tóth, G.; Kapus, K.;

Hesszenberger, D.; Pohl, M.; Kósa, G.;

Kiss, J.; Pusch, G.; Fejes, É.; Tibold, A.;

Feher, G. Prevalence and Risk Factors of Internet Addiction among Hungarian High School Teachers. Life 2021, 11, 194. https://doi.org/ 10.3390/life11030194

Academic Editor: Nicola Smania

Received: 6 January 2021

Accepted: 27 February 2021

Published: 3 March 2021

Publisher's Note: MDPI stays neutral with regard to jurisdictional claims in published maps and institutional affiliations.

Copyright: (c) 2021 by the authors. Licensee MDPI, Basel, Switzerland. This article is an open access article distributed under the terms and conditions of the Creative Commons Attribution (CC BY) license (https:/ / creativecommons.org/licenses/by/ $4.0 /)$.

\begin{abstract}
The extensive availability of internet has led to the the recognition of problematic internet use (so called internet addiction, IA) mostly involving adolescents. There is limited data about the prevalence of IA in adults. Here we present a study focusing on the prevalence and risk factors of internet addiction among high school teachers. Overall 2500 paper-based questionnaires were successfully delivered and 1817 responses received (response rate of $72.7 \%$ ). In our study 1194 females (65.7\%) and 623 males (34.3\%) participated. In a multivariate analysis including of all factors (demographic data, internet habits, comorbidity etc.) age <35 years (OR: 6.098, CI: 5.09-7.08, $p<0.001)$, male gender ( $\mathrm{OR}=5.413$, CI: 4.39-6.18, $p=0.002)$, surfing on the internet $>5$ h daily (OR 2.568, CI: 2.03-3.39, $p<0.001$ ), having no children (OR: 1.353, CI: 1.13-1.99, $p=0.0248$ ), and having secondary employment (OR $=11.377, \mathrm{CI}: 8.67-13.07, p=0.001)$ were significantly associated with internet addiction. This is the first study from Hungary showing the prevalence and risk factors of internet addiction among high school teachers. A small, but significant proportion suffered from IA. Our study also draws attention to the risk factors of IA such as younger age, family status and working type.
\end{abstract}

Keywords: internet addiction; adult prevalence; risk factor; teacher

\section{Introduction}

The widespread use of internet has dramatically changed our lives by the 21st century. Although this technological revolution has improved many aspects of our lives and it is now an essential part of the everyday routine, including work, private life and social functioning, many studies reported the misuse of internet (problematic internet use, internet addiction; IA) as summarized in a recent meta-analysis including 113 epidemiologic studies covering 693,306 subjects showed that the pooled prevalence of internet addiction was 7.02\% (95\% CI, 6.09-8.08\%) in the population aged 7-60 years [1]. Age (adolescent samples), lower cutoff scores (and type of questionnaire), sample size (more common is smaller samples), and country of origin (more frequent in Asian studies) were significant predictors of higher prevalence $[2,3]$.

The individual suffering from internet addiction may be not aware of it and the symptoms remain unrecognized by his or her relatives, friends and colleagues [4]. 
IA may be classified as a compulsive-impulsive spectrum disorder based on symptomatology, but it has been under considerable research, and is not included in the recently published 5th edition of the Diagnostic and Statistical Manual DSM-V $[5,6]$.

IA seems to have several risk factors such as younger age at the start of internet use, male gender, daily time interval, goal of internet use and low socioeconomic status [5,7]. Psychosocial factors such as low self-concept and and lack of family support are also associated with problematic internet use [8,9]. Problematic internet use seems to be associated with medical conditions such as anxiety, depression, drug abuse and malnutrition $[10,11]$.

IA is mainly studied in adolescents aged 14-18 (who may be at heightened risk for mental health problems), raising the possibility of school based prevention [12,13]. Their teachers also have increased opportunities to use the internet. Therefore we targeted high-school teachers who are amongst the first lines of prevention.

The aim of our research was to detect the prevalence of internet addiction among high school teachers and its risk factors including age, gender, family type, working years, daily internet use, and the goal of being online. Medical conditions may be associated with IA such as smoking, alcohol and drug intake, hypertension, diabetes, ischemic heart disease, musculoskeletal pain, and history of depression were also recorded.

\section{Materials and Methods}

This prospective, cross-sectional, paper-based questionnaire study was conducted between January 2020 and August 2020 in 14 sites in Hungary. The names of the included schools are mentioned in the Acknowledgement part.

The study was approved by the Ethical Committee of the University of Pecs (8434-PTE 2020). Consent was obtained from the individuals prior to data collection. Paper-based questionnaires were delivered to those who had previously agreed to participate by signing an informed consent.

Inclusion criteria were working as a high school teacher, being between 18 and 65 years of age and being employed at the time of the study apart from the type of employment (public servant, subcontractor, etc.).

Exclusion criteria were being under 18 or over 65 years of age, being on permanent leave or refusing to participate in the study.

Demographic criteria included age, gender, marital status, number of children, type of work, years spent with work, work schedule, legal relation, and secondary employment.

Included risk factors and medical conditions were smoking, alcohol and illicit drug intake; diabetes, hypertension, ischemic heart disease, musculoskeletal pain, and history of depression.

As there are no clear diagnostic criteria for the internet addiction it is highly recommended to measure excessive internet use with a continuous questionnaire [4]. We chose the problematic internet use questionnaire (PIUQ) because its structure tightly adheres to the proposed diagnostic criteria for internet addiction and was created based on the clinimetric and psychometric analysis of Young's internet addiction test independently validated by several groups and used in our previous published work [14-17]. The questionnaire contains 18 items, each scored on a 5-point Likert-type scale ranging from 1 (never) to 5 (always). A confirmatory factor analysis verified the three factor model of the questionnaire, each subscale contains six items. Obsession subscale refers to obsessive thinking about the internet (daydreaming, rumination, and fantasizing) and withdrawal symptoms caused by the lack of internet use (anxiety and depression) ("How often do you feel tense, irritated, or stressed if you cannot use the Internet for as long as you want to?"). Neglect subscale contains items about neglecting everyday activities, social life, and essential needs ("How often do you spend time online when you'd rather sleep?"). Control disorder subscale reflects difficulties in controlling time spent on the Internet ("How often do you realize saying when you are online, "just a couple of more minutes and I will stop"?"). Since in this study we focused on global psychological consequences of internet addiction, we used PIUQ total score in statistical analyses, which was computed by 
summing the scores on all the items of the scale. A total score exceeding 41 points suggests internet addiction [15].

Data were evaluated as means \pm SD (standard deviation) by Student's $t$-test, the chi square test and the Pearson's rank-order correlation. Logistic regression analysis was used to determine the significance of the different parameters as independent risk factors of IA. The analysis was performed with appropriate adjustments for differences in risk factors and medication usage. For all odds ratios, an exact CI of $95 \%$ was constructed in our study. Data analysis was performed using SPSS (version 22.0, IBM, New York, NY, USA).

\section{Results}

\subsection{Baseline Characteristics}

Overall 2500 paper-based questionnaires were successfully delivered and 1817 responses received (response rate of $72.7 \%$ ).

In our study 1194 females $(65.7 \%)$ and 623 males (34.3\%) participated. Age distribution was the following: $18-25$ years $2.5 \%$ (46/1817), $26-35$ years $11.9 \%(217 / 1817), 36-45$ years $31.8 \%$ (577/1817), $46-55$ years $33.1 \%$ (602/1817), $56-62$ years $15.7 \%(285 / 1817)$, and $5.0 \%$ above $62(90 / 1817)$ (Table 1)

Table 1. Baseline characteristics of the study population $(\mathrm{N}=1817)$.

\begin{tabular}{|c|c|}
\hline $\begin{array}{l}\text { Gender } \\
\text { Female } \\
\text { Male }\end{array}$ & $\begin{array}{c}1194(65.7 \%) \\
623(34.3 \%)\end{array}$ \\
\hline $\begin{array}{c}\text { Age } \\
\text { 18-25 years } \\
\text { 26-35 years } \\
36-45 \text { years } \\
\text { 46-55 years } \\
56-62 \text { years } \\
\text { more than } 62 \text { years }\end{array}$ & $\begin{array}{c}46(2.5 \%) \\
217(11.9 \%) \\
577(31.8 \%) \\
602(33.1 \%) \\
285(15.7 \%) \\
90(5.0 \%)\end{array}$ \\
\hline $\begin{array}{l}\text { Marital Status } \\
\text { single } \\
\text { relationship } \\
\text { married } \\
\text { divorced/widow }\end{array}$ & $\begin{array}{c}263(14.5 \%) \\
257(14.1 \%) \\
1082(59.5 \%) \\
215(11.9 \%)\end{array}$ \\
\hline $\begin{array}{l}\text { Number of Children } \\
\text { have no children } \\
1 \text { child } \\
2 \text { children } \\
\text { more than } 3 \text { children }\end{array}$ & $\begin{array}{l}419(23.1 \%) \\
414(22.8 \%) \\
706(38.9 \%) \\
278(15.2 \%)\end{array}$ \\
\hline $\begin{array}{l}\text { Work Schedule } \\
\text { regular } \\
\text { shifts }\end{array}$ & $\begin{array}{c}1735(95.5 \%) \\
82(4.5 \%)\end{array}$ \\
\hline $\begin{array}{c}\text { Graduation } \\
\text { elementary } \\
\text { secondary education } \\
\text { higher education }\end{array}$ & $\begin{array}{c}9(0.5 \%) \\
105(5.8 \%) \\
1703(93.7 \%)\end{array}$ \\
\hline $\begin{array}{c}\text { Years Spent with Work } \\
1-12 \text { months } \\
1-5 \text { years } \\
6-10 \text { years } \\
11-20 \text { years } \\
21-30 \text { years } \\
31-40 \text { years } \\
\text { more than } 40 \text { years }\end{array}$ & $\begin{array}{c}54(2.9 \%) \\
205(11.3 \%) \\
263(14.5 \%) \\
584(32.1 \%) \\
383(21.1 \%) \\
288(15.9 \%) \\
40(2.2 \%)\end{array}$ \\
\hline $\begin{array}{c}\text { Secondary Employment } \\
\text { no } \\
\text { yes }\end{array}$ & $\begin{array}{c}1584(87.2 \%) \\
233(12.8 \%)\end{array}$ \\
\hline
\end{tabular}


Of the participants, $73.6 \%(1339 / 1817)$ were married or lived in a relationship, $26.4 \%(478 / 1817)$ were single. $23.1 \%(419 / 1817)$ had no children, $22.8 \%(414 / 1817)$ had one child, 38.9\% (706/1817) had two, and 15.2\% (278/1817) had three or more children.

Of the participants, $0.5 \%(9 / 1817)$ had elementary degree, $5.8 \%(105 / 1817)$ had secondary education, and $93.7 \%(1703 / 1817)$ had university graduation.

Of the participants, $2.9 \%(54 / 1817)$ have been employed for less than a year. $37.0 \%(671 / 1817)$ of the study population have been working between 21 and 40 years, 32.1\% (584/1817) have been working between 11 and 20 years, and 2.2\% (40/1817) more than 40 years. $12.8 \%$ $(233 / 1817)$ had also a secondary employment (Table 1$)$.

\subsection{Risk Factors and Previous Diseases}

Of the participants, $15.1 \%(275 / 1817)$ were regular smokers, $5.1 \%(93 / 1817)$ were taking alcohol, and $2.9 \%(52 / 1817)$ were taking illicit drugs more or less regularly.

Of the participants, $22.8 \%(414 / 1817)$ had hypertension, $7.4 \%(135 / 1817)$ were diabetic, $10.2 \%$ had ischemic heart disease (186/1817), 8.0\% (146/1817) suffered from musculoskeletal pain, and $1.5 \%(27 / 1817)$ had a history of depression (Table 2).

Table 2. Concomitant diseases, substance abuse, and internet use in the study population.

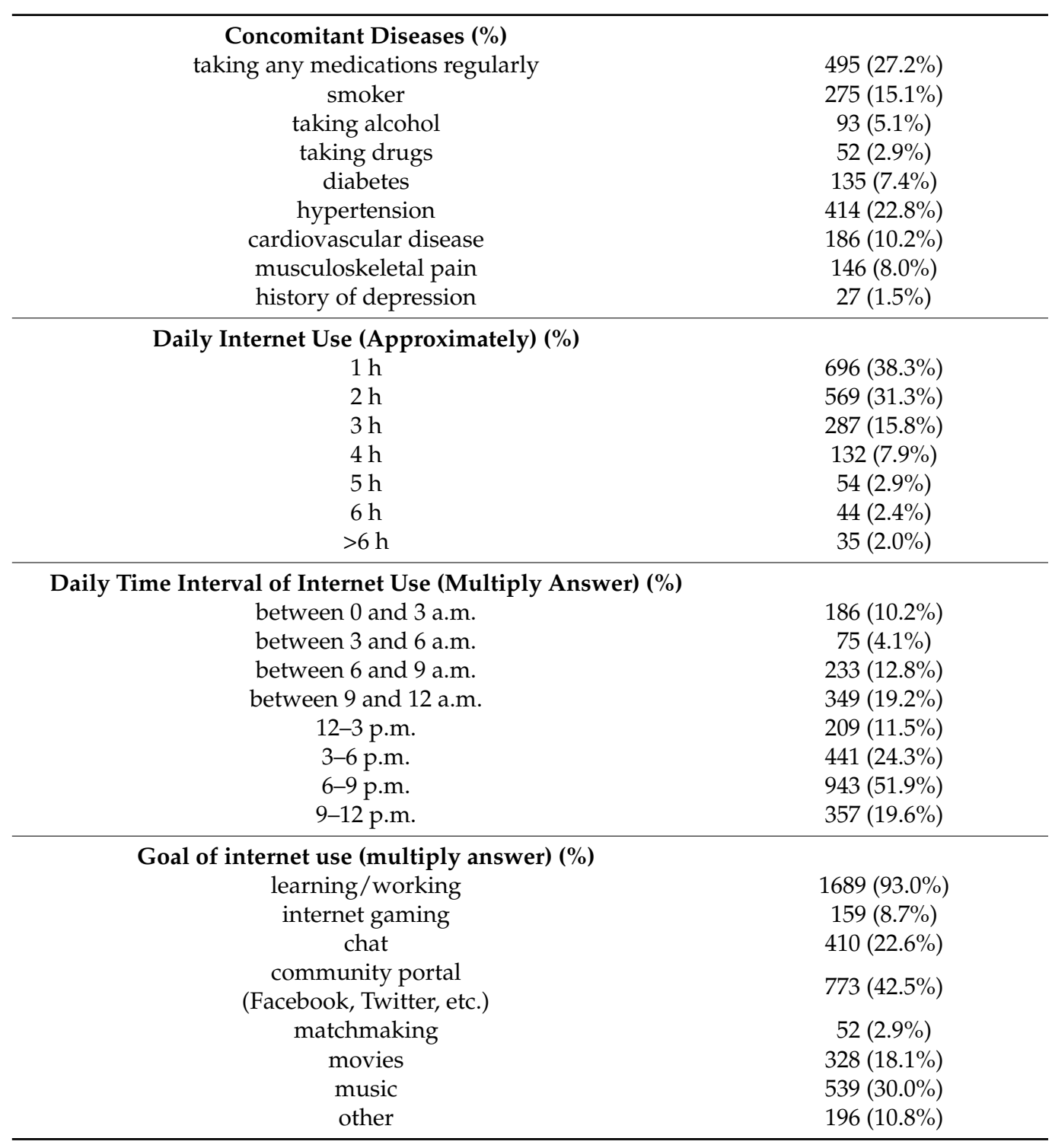




\subsection{Duration and Goal of Internet Use}

Of the participants, $38.3 \%(696 / 1817)$ spent less than one hour online and $2.0 \%$ $(35 / 1817)$ used the internet more than six hours a day. More than half of the examined workers preferred being online between 6 and 9 p.m. (51.9\%, 943/1817). The main goals of internet surfing were to every day work $93.0 \%(1689 / 1817)$, visit community portals $42.5 \%$ (773/1817), and listening to music in 30.0\% (539/1817). Detailed data can be seen in Table 2.

\subsection{Internet Addiction}

Internet addiction was detected in 5.2\% (95/1817) based on the problematic internet use questionnaire. Internet addiction was more common in males $(62.1 \mathrm{vs.} 32.7 \%, p=0.001)$ and workers below 35 years of age ( 29.5 vs. $13.6 \%, p<0.001)$. Being middle-aged or older was protective against IA ( 54.8 vs. $34.7 \%, p=0.001$, mostly driven by ages between 45 and 55 ).

IA was more prevalent among singles ( $23.1 \mathrm{vs.} 14 \% \%, p=0.011)$ and childless ( $34.7 \mathrm{vs}$. $22.4 \%, p=0.004$ ) (Table 3). Living in a relationship (74.2 vs. $63.1 \%, p=0.018$, mostly driven by being married) or having at least two children ( 55 vs. $40 \%, p=0.004$, mostly driven by having two children) were protective against IA.

Table 3. Comparison of baseline characteristics of the study subgroups. ${ }^{*} p<0.001 ;{ }^{*} p<0.05$.

\begin{tabular}{|c|c|c|}
\hline & Not Addicted to Internet $(n=1722)$ & Internet Addiction $(n=95)$ \\
\hline \multicolumn{3}{|c|}{ Gender } \\
\hline Male & $564(32.7 \%)$ & $59(62.1 \%) *$ \\
\hline Female & $1158(67.2 \%)$ & $36(37.9 \%)$ \\
\hline \multicolumn{3}{|c|}{ Age (Years) } \\
\hline $18-25$ years & $39(2.3 \%)$ & $7(7.4 \%) *$ \\
\hline 26-35 years & $196(11.4 \%)$ & $21(22.1 \%) *$ \\
\hline $36-45$ years & $543(31.5 \%)$ & $34(35.8 \%)$ \\
\hline $46-55$ years & $585(34 \%)$ & $17(17.9 \%) *$ \\
\hline $56-62$ years & $273(15.8 \%)$ & $12(12.6 \%)$ \\
\hline more than 62 years & $86(5 \%)$ & $4(4.2 \%)$ \\
\hline \multicolumn{3}{|c|}{ Marital Status (\%) } \\
\hline single & $241(14 \%)$ & $22(23.1 \%) *$ \\
\hline relationship & $240(14 \%)$ & $17(17.9 \%)$ \\
\hline married & $1037(60.2 \%)$ & $43(45.3 \%) *$ \\
\hline divorced / widow & $202(11.7 \%)$ & $13(13.7 \%)$ \\
\hline \multicolumn{3}{|c|}{ Number of Children } \\
\hline having no children & $386(22.4 \%)$ & $33(34.7 \%) *$ \\
\hline 1 child & $390(22.6 \%)$ & $24(25.3 \%)$ \\
\hline 2 children & $683(39.7 \%)$ & $23(24.2 \%) *$ \\
\hline more than 3 children & $263(15.3 \%)$ & $15(15.8 \%)$ \\
\hline \multicolumn{3}{|c|}{ Work Schedule } \\
\hline regular & $1643(95.4 \%)$ & $92(96.8 \%)$ \\
\hline shifts & $79(4.6 \%)$ & $3(3.2 \%)$ \\
\hline \multicolumn{3}{|c|}{ Graduation } \\
\hline elementary & $6(0.3 \%)$ & $3(3.2 \%) * *$ \\
\hline secondary education & $108(6.3 \%)$ & $7(7.4 \%)$ \\
\hline higher education & $1618(96.9 \%)$ & $85(89.5 \%)$ \\
\hline \multicolumn{3}{|c|}{ Years Spent with Work } \\
\hline $1-12$ months & $47(2.7 \%)$ & $7(7.3 \%) *$ \\
\hline $1-5$ years & $191(11.1 \%)$ & $14(14.7 \%)$ \\
\hline $6-10$ years & $246(14.3 \%)$ & $17(17.9 \%)$ \\
\hline $11-20$ years & $547(31.8 \%)$ & $37(38.9 \%)$ \\
\hline 21-30 years & $373(21.7 \%)$ & $10(10.5 \%) *$ \\
\hline $31-40$ years & $281(16.3 \%)$ & $7(7.4 \%) *$ \\
\hline more than 40 years & $37(2.1 \%)$ & $3(3.2 \%)$ \\
\hline \multicolumn{3}{|c|}{ Secondary Employment } \\
\hline no & $1503(87.3 \%)$ & $14(14.7 \%)$ \\
\hline yes & $219(12.7 \%)$ & $81(85.3 \%) * *$ \\
\hline
\end{tabular}

Lower educational level was also associated with IA (3.2 vs. $0.3 \%, p<0.001)$. 
Working for less than a year was a predictor of IA ( 7.3 vs. $2.7 \%, p=0.009)$, while working for $>20$ years was protective ( 40.1 vs. $21.1 \%, p<0.001)$ (Table 3$)$. Having a secondary employment was significantly associated with problematic internet use (85.3 vs. $12.7 \%$, $p<0.001)$.

There was a significant association between the duration of being online and being addicted to the internet $(\mathrm{r}=0.36, p<0.001)$ (Table 4$)$. The cut-off of spending $5 \mathrm{~h}$ or more online predicted IA. We found no association between the daily time interval of internet use and IA.

Table 4. Comparison of concomitant diseases, substance abuse, and internet use in the study subgroups.

\begin{tabular}{|c|c|c|}
\hline & $\begin{array}{l}\text { Not Addicted to Internet } \\
\qquad(n=1722)\end{array}$ & $\begin{array}{l}\text { Internet Addiction } \\
\quad(n=95)\end{array}$ \\
\hline \multicolumn{3}{|c|}{ Concomitant Diseases } \\
\hline $\begin{array}{l}\text { taking any medication } \\
\text { regularly }\end{array}$ & $475(27.6 \%)$ & $20(21.1 \%)$ \\
\hline smoker & $242(14.1 \%)$ & $33(34.7 \%) * *$ \\
\hline taking alcohol & $76(4.4 \%)$ & $17(17.9 \%) * *$ \\
\hline taking drugs & $37(2.1 \%)$ & $15(15.8 \%) * *$ \\
\hline diabetes & $122(7.1 \%)$ & $13(13.7 \%) *$ \\
\hline hypertension & $387(22.5 \%)$ & $27(28.4 \%)$ \\
\hline cardiovascular disease & $175(10.2 \%)$ & $11(11.6 \%)$ \\
\hline musculoskeletal pain & $136(7.9 \%)$ & $10(10.5 \%)$ \\
\hline history of depression & $19(1.1 \%)$ & $8(8.4 \%) * *$ \\
\hline \multicolumn{3}{|c|}{ Daily Internet Use (Approximately) } \\
\hline $1 \mathrm{~h}$ & $684(39.7 \%)$ & $12(12.6 \%) * *$ \\
\hline $2 \mathrm{~h}$ & $552(32.1 \%)$ & $17(17.9 \%) *$ \\
\hline $3 \mathrm{~h}$ & $265(15.4 \%)$ & $22(23.2 \%) *$ \\
\hline $4 \mathrm{~h}$ & $114(6.6 \%)$ & $18(18.9 \%) *$ \\
\hline $5 \mathrm{~h}$ & $46(2.7 \%)$ & $14(14.7 \%)^{* *}$ \\
\hline $6 \mathrm{~h}$ & $30(1.7 \%)$ & $4(4.2 \%)$ \\
\hline$>6 \mathrm{~h}$ & $31(1.7 \%)$ & $8(8.4 \%)^{* *}$ \\
\hline \multicolumn{3}{|c|}{ Daily Time Interval of Internet Use (Multiply Answer) } \\
\hline between 0 and 3 a.m. & $178(10.3 \%)$ & $8(8.4 \%)$ \\
\hline between 3 and 6 a.m. & $69(4 \%)$ & $6(6.3 \%)$ \\
\hline between 6 and 9 a.m. & $218(12.7 \%)$ & $15(15.8 \%)$ \\
\hline between 9 and 12 a.m. & $335(19.5 \%)$ & $14(14.7 \%)$ \\
\hline 12-3 p.m. & $196(11.4 \%)$ & $13(13.7 \%)$ \\
\hline 3-6 p.m. & $410(23.8 \%)$ & $31(32.6 \%)$ \\
\hline 6-9 p.m. & $894(51.9 \%)$ & $49(51.6 \%)$ \\
\hline 9.12 p.m. & $332(19.3 \%)$ & $25(26.3 \%)$ \\
\hline \multicolumn{3}{|c|}{ Goal of Internet Use (Multiply Answer) } \\
\hline learning/working & $1613(93.7 \%)$ & $76(80 \%) * *$ \\
\hline internet gaming & $135(7.8 \%)$ & $24(25.2 \%) * *$ \\
\hline chat & $372(21.6 \%)$ & $38(40) * *$ \\
\hline $\begin{array}{c}\text { community portal } \\
\text { (Facebook, Twitter, etc.) }\end{array}$ & $724(42 \%)$ & $49(51.6 \%)$ \\
\hline matchmaking & $41(2.4 \%)$ & $11(11.6 \%) * *$ \\
\hline movies & $308(17.9 \%)$ & $20(21 \%)$ \\
\hline music & $514(29.8 \%)$ & $25(26.3 \%)$ \\
\hline other & $188(10.9 \%)$ & $8(8.4 \%)$ \\
\hline
\end{tabular}

Among the types of internet services internet gaming ( 25.2 vs. $7.8 \%$ ), chatting ( $40 \mathrm{vs}$. $21.6 \%$ ), and matchmaking (11.6 vs. $2.4 \%, p<0.001$ in all cases) were significantly associated with IA (Table 4).

Internet addiction was more prevalent among smokers ( $34.7 \mathrm{vs.} 14.1 \%)$, alcohol, and drug users $(17.9 \%$ vs. $4.4 \%, 15.8 \%$ vs. $2.1 \%, p<0.001$ in all cases). Diabetes (13.7 vs. $7.1 \%$, 
$p=0.016)$ and history of depression $(8.4$ vs. $1.1 \%, p<0.001)$ were significantly associated with problematic internet use (Table 4).

In a multivariate analysis including all factors (demographic data, internet habits, comorbidity, etc.), age $<35$ years (OR: 6.098, CI: 5.09-7.08, $p<0.001)$, male gender (OR $=5.413$, CI: $4.39-6.18, p=0.002$ ), surfing on the internet $>5$ h daily (OR 2.568, CI: 2.03-3.39, $p<0.001$ ), having no children (OR: 1.353, CI: 1.13-1.99, $p=0.0248$ ), and having secondary employment $(\mathrm{OR}=11.377, \mathrm{CI}: 8.67-13.07, p=0.001)$ were significantly associated with internet addiction (Table 5).

Table 5. Risk factors associated with internet addiction in a multivariate analysis.

\begin{tabular}{cccc}
\hline Risk Factor & OR & CI & $p$ Value \\
\hline age $<$ 35 years & 6.098 & $5.09-7.08$ & $<0.001$ \\
male gender & 5.413 & $4.39-6.18$ & 0.002 \\
$>$ 5 h daily internet use & 2.568 & $2.03-3.39$ & $<0.001$ \\
having no children & 1.353 & $1.13-1.99$ & 0.0248 \\
having secondary employment & 11.377 & $8.67-13.07$ & 0.001 \\
\hline
\end{tabular}

\section{Discussion}

Internet addiction is a well known phenomena among adolescents, but only few studies focused on its prevalence among adults, and we found only one study including (their) teachers [12].

In a recent meta analysis the rate of internet addiction was $7.2 \%$ in the general population, which is far lower than it would be expected by the IA rate of adolescents, which can be as high as $20 \%[1,18]$. In out study the rate of IA was $5.2 \%$, which is comparable to the above mentioned findings.

Internet addiction was more common in males in our study and confirmed the hypothesis of gender-related differences in this addictive behavior [19]. Internet addiction was also more prevalent entrants up to the age of 35 underlying the importance lower age of first internet use and the protective role of increasing age [20,21]. In a multivariate analysis younger age and male gender remained significant predictors of IA.

Singles, childless ones are at higher risk of IA based on our study. The protective role of living in a relationship and having children (and increasing age) was also reported by a previous study [22]. Having no children remained a significant predictor of IA in a multivariate analysis.

Problematic internet use was associated with chatting, gaming, and watching movies taking the types of internet use into account. This is in concordance with recent results showing different distribution patterns of IA based on sex and specific internet services, chatting, gaming, and watching movies (mostly pornography) were strongly associated with this phenomena [23]. Males overwhelmingly use the internet for gaming, while females are mostly involved in blogging and messenger/chatting, which might be related to well-established evidence that females are more interpersonally oriented, while males are more information/task oriented [23]. However, the goal of internet use lost its predictive value in a multivariate analysis.

The greater internet use was associated with increased prevalence of addiction, previous studies showed being $>2 \mathrm{~h}$ online as the predecessor of addiction [24,25]. We found the cut-off value of $5 \mathrm{~h}$ or more daily internet use as an independent risk factor of IA, which is in concordance with very recent results [25].

Internet addicts reported night time as the preferred time of internet use underlying the addictive nature of the phenomena among adolescents [26]. Bedtime and wake-up time internet use on weekdays and holidays were also significantly associated with later problematic internet use/gaming disorder in children [27]. Our study could not confirm the role of the daily time interval as a risk factor of IA among teachers.

IA was also associated with substance abuse such as alcohol or drugs and a history of depression. The association of IA and psychiatric symptoms is not well understood. 
An underlying psychopathology (history of addiction) may precipitate internet addiction or IA may lead to the onset of consequent behavioral abnormalities and mood disorders, and finally they may enhance each other [28]. Drug addicts who use stimulants may have specific vulnerability to IA based on a recent study [29].

Diabetes was also significantly associated with internet addiction. Based on a recent meta-analysis each additional $1 \mathrm{~h} / \mathrm{d}$ of internet use was associated with $8 \%$ increased odds of overweight and obesity, which can lead to metabolic syndrome, diabetes, and cardiovascular morbidity [30]. However, a multivariate analysis could not confirm the predictive roles of substance abuse, depression, and diabetes as risk factors of IA.

Secondary employment was also associated with IA and also remained a significant predictor in a multivariate analysis. Being overwhelmed with work can lead to distress and social anxiety, which seem to be predecessors of problematic internet use [26]. Furthermore, overwork can be the predictor of burnout and a recent study showed the possible association of burnout and internet addiction in adolescents [31].

IA has been under considerable research, and has generated controversy, debate, and quarreling among expert researchers, healthcare, and non-healthcare professionals due to insufficient data, poor quality research, and the lack of randomized studies [1]. However, internet addiction seems to be more than just the consequence of mental instability of adolescents. It can be associated with atrophy in the prefrontal and striatal areas similar to other type of addictions and can be related to psychiatric diseases, overweight (metabolic syndrome/diabetes), and chronic musculoskeletal pain [29,31,32]. Furthermore, pooled estimate of the persistence can be as high as 50\% [33]. Our study confirmed the presence of internet addiction among adults and its association with some of the above mentioned medical conditions underlying the importance of recognition to avoid further complications.

In summary, this is the first study from Hungary showing the prevalence and risk factors of internet addiction among high school teachers. A small, but significant proportion suffered from IA. Our study also draws attention to the risk factors of IA such as younger age, family status, and working type.

Finally, our article has some limitations. Although it was a prospective study in nature including more than 1700 teachers, it was not representative of internet addiction in the general/adult population. As it was a questionnaire based survey, physical examination was not carried out and we had no detailed information about the medical history of the study population such as type and duration of medical disorders. The above mentioned limitations may influence our findings. Additionally, finally, follow-up was not carried out.

Author Contributions: Conceptualization, G.F. and A.T.; methodology, G.P., É.F.; software, J.K.; validation, G.F. and É.F.; formal analysis, M.P. and É.F.; investigation, G.P., G.T. and K.K.; data curation, G.K.; writing — original draft preparation, K.K. and G.T.; writing—review and editing, G.F., G.P. and A.T.; visualization, D.H.; supervision, G.F.; project administration, D.H.; funding acquisition, G.F. All authors have read and agreed to the published version of the manuscript.

Funding: This research was funded by NKFI (OTKA)-135316 project.

Institutional Review Board Statement: Ethics approval and consent to participate: The study protocol conforms to the ethical guidelines of the 1975 Declaration of Helsinki as reflected in a priori approval by the Regional Ethical Committee at the University of Pécs, Pécs, Hungary as seen above.

Informed Consent Statement: Not applicable.

Data Availability Statement: The dataset supporting the conclusions of this article is available on request to the corresponding author.

Acknowledgments: We would like to thank for the following schools for their help: Nyíregyházi Szakképzési Centrum, Budapesti Komplex Szakképzési Centrum. Kecskeméti Szakképzési Centrum, Kiskunhalasi Szakképzési Centrum, Cseppkő Gyermekotthoni Központ, Szolnoki Szakképzési Centrum, Somogy megye, Csurgó iskolái, Pécsi Református Kollégium Gimnáziuma, Általános Iskolája és Óvodája, Kiskőrösi Tankerületi Központ iskolái, Constantinum Katolikus Óvoda, Általános 
Iskola, Gimnázium, Szakgimnázium, Kollégium, Kiskunfélegyházi Szent Benedek PG Középiskola, Szent Benedek Iskola Budaörsi Tagintézmény, Kiskunhalasi iskolák pedagógusai, Észak-Budapesti Tankerületi Központ.

Conflicts of Interest: The authors declare no conflict of interest.

\section{References}

1. Pan, Y.C.; Chiu, Y.C.; Lin, Y.H. Systematic review and meta-analysis of epidemiology of internet addiction. Neurosci. Biobehav. Rev. 2020, 118, 612-622. [CrossRef]

2. Stevens, M.W.; Dorstyn, D.; Delfabbro, P.H.; King, D.L. Global prevalence of gaming disorder: A systematic review and meta-analysis. Aust. N. Z. J. Psychiatry 2020, 2020. [CrossRef] [PubMed]

3. Chia, D.X.Y.; Ng, C.W.L.; Kandasami, G.; Seow, M.Y.L.; Choo, C.C.; Chew, P.K.H.; Lee, C.; Zhang, A.M.W. Prevalence of Internet Addiction and Gaming Disorders in Southeast Asia: A Meta-Analysis. Int. J. Environ. Res. Public Health 2020, 17, 2582. [CrossRef]

4. Zsidó, A.N.; Darnai, G.; Inhóf, O.; Perlaki, G.; Orsi, G.; Nagy, S.A.; Lábadi, B.; Lénárd, K.; Kovács, N.; Dóczi, T.; et al. Differentiation between young adult Internet addicts, smokers, and healthy controls by the interaction between impulsivity and temporal lobe thickness. J. Behav. Addict. 2019, 8, 35-47. [CrossRef]

5. Cheng, Y.S.; Tseng, P.T.; Lin, P.Y.; Chen, T.Y.; Stubbs, B.; Carvalho, A.F.; Wu, C.K.; Chen, Y.W.; Wu, M.K. Internet Addiction and Its Relationship With Suicidal Behaviors: A Meta-Analysis of Multinational Observational Studies. J. Clin. Psychiatry 2018, 79, 17r11761. [CrossRef] [PubMed]

6. American Psychiatric Association. Diagnostic and Statistical Manual of Mental Disorders, 5th ed.; American Psychiatric Publishing: Washington, DC, USA, 2013.

7. Petruzelka, B.; Vacek, J.; Gavurova, B.; Kubak, M.; Gabrhelik, R.; Rogalewicz, V.; Bartak, M. Interaction of Socioeconomic Status with Risky Internet Use, Gambling and Substance Use in Adolescents from a Structurally Disadvantaged Region in Central Europe. Int. J. Environ. Res. Public Health 2020, 17, 4803. [CrossRef] [PubMed]

8. Cheng, C.; Li, A.Y.-L. Internet Addiction Prevalence and Quality of (Real) Life: A Meta-Analysis of 31 Nations Across Seven World Regions. Cyberpsychol. Behav. Soc. Netw. 2014, 17, 755-760. [CrossRef] [PubMed]

9. Chi, X.; Hong, X.; Chen, X. Profiles and sociodemographic correlates of Internet addiction in early adolescents in southern China. Addict. Behav. 2020, 106, 106385. [CrossRef]

10. Hinojo-Lucena, F.J.; Aznar-Díaz, I.; Cáceres-Reche, M.P.; Trujillo-Torres, J.M.; Romero-Rodríguez, J.M. Problematic Internet Use as a Predictor of Eating Disorders in Students: A Systematic Review and Meta-Analysis Study. Nutrients 2019, 11, 2151. [CrossRef]

11. Ioannidis, K.; Hook, R.; Goudriaan, A.E.; Vlies, S.; Fineberg, N.A.; Grant, J.E.; Chamberlain, S.R. Cognitive deficits in problematic internet use: Meta-analysis of 40 studies. Br. J. Psychiatry 2019, 215, 639-646. [CrossRef] [PubMed]

12. Iwaibara, A.; Fukuda, M.; Tsumura, H.; Kanda, H. At-risk Internet addiction and related factors among junior high school teachers-based on a nationwide cross-sectional study in Japan. Environ. Health Prev. Med. 2019, 24, 3. [CrossRef]

13. Throuvala, M.A.; Griffiths, M.D.; Rennoldson, M.; Kuss, D.J. School-based Prevention for Adolescent Internet Addiction: Prevention is the Key. A Systematic Literature Review. Curr. Neuropharmacol. 2019, 17, 507-525. [CrossRef]

14. Demetrovics, Z.; Szeredi, B.; Rózsa, S. The three-factor model of Internet addiction: The development of the Problematic Internet Use Questionnaire. Behav. Res. Methods 2008, 40, 563-574. [CrossRef]

15. Kovács, M.; Makkos, A.; Pintér, D.; Juhász, A.; Darnai, G.; Karádi, K.; Janszky, J.; Kovács, N. Screening for Problematic Internet Use May Help Identify Impulse Control Disorders in Parkinson's Disease. Behav. Neurol. 2019, 2019, 4925015. [CrossRef] [PubMed]

16. Toth, G.; Kapus, K.; Hesszenberger, D.; Pohl, M.; Kosa, G.; Kiss, J.; Pusch, G.; Fejes, E.; Tibold, A.; Feher, G. Internet Addiction and Burnout in A Single Hospital: Is There Any Association? Int. J. Environ. Res. Public Health 2021, 18, 615. [CrossRef] [PubMed]

17. Kern, L.; Acier, D. French adaptation of the Problematic Internet Use Questionnaire. L'Évolution Psychiatri. 2013, 78, 357-371. [CrossRef]

18. Weinstein, A.; Lejoyeux, M. Internet addiction or excessive internet use. Am. J. Drug Alcohol. Abuse 2010, 36, 277-283. [CrossRef]

19. Tomaszek, K.; Muchacka-Cymerman, A. Sex Differences in the Relationship between Student School Burnout and Problematic Internet Use among Adolescents. Int. J. Environ. Res. Public Health 2019, 16, 4107. [CrossRef] [PubMed]

20. Grover, S.; Sahoo, S.; Bhalla, A.; Avasthi, A. Problematic internet use and its correlates among resident doctors of a tertiary care hospital of North India: A cross-sectional study. Asian J. Psychiatry 2019, 39, 42-47. [CrossRef]

21. Chiu, C.-J. Relationship between Internet Behaviors and Social Engagement in Middle-Aged and Older Adults in Taiwan. Int. J. Environ. Res. Public Health 2019, 16, 416. [CrossRef]

22. Avci, D.K.; Sahin, H.A. Relationship Between Burnout Syndrome and Internet Addiction, and the Risk Factors in Healthcare Employees in a University Hospital. Konuralp Tıp Derg. 2017, 9, 78-85.

23. Kim, K.M.; Kim, H.; Choi, J.-W.; Kim, S.Y.; Kim, J.W. What Types of Internet Services Make Adolescents Addicted? Correlates of Problematic Internet Use. Neuropsychiatr. Dis. Treat. 2020, 16, 1031-1041. [CrossRef]

24. Mamun, M.; Griffiths, M.D. The assessment of internet addiction in Bangladesh: Why are prevalence rates so different? Asian J. Psychiatry 2019, 40, 46-47. [CrossRef]

25. Chandrima, R.M.; Kircaburun, K.; Kabir, H.; Riaz, B.K.; Kuss, D.J.; Griffiths, M.D.; Mamun, M.A. Adolescent problematic internet use and parental mediation: A Bangladeshi structured interview study. Addict. Behav. Rep. 2020, 12, 100288. [CrossRef] [PubMed] 
26. Tenzin, K.; Dorji, T.; Choeda, T.; Wangdi, P.; Oo, M.M.; Tripathy, J.P.; Tenzin, T.; Tobgay, T. Internet Addiction among Secondary School Adolescents: A Mixed Methods Study. J. Nepal Med. Assoc. 2019, 57, 344-351. [CrossRef]

27. Yen, J.-Y.; Ko, C.-H.; Yen, C.-F.; Chen, S.-H.; Chung, W.-L.; Chen, C.-C. Psychiatric symptoms in adolescents with Internet addiction: Comparison with substance use. Psychiatry Clin. Neurosci. 2008, 62, 9-16. [CrossRef] [PubMed]

28. Baroni, S.; Marazziti, D.; Mucci, F.; Diadema, E.; Dell'Osso, L. Problematic Internet use in drug addicts under treatment in public rehab centers. World J. Psychiatry 2019, 9, 55-64. [CrossRef] [PubMed]

29. Aghasi, M.; Matinfar, A.; Golzarand, M.; Salari-Moghaddam, A.; Ebrahimpour-Koujan, S. Internet Use in Relation to Overweight and Obesity: A Systematic Review and Meta-Analysis of Cross-Sectional Studies. Adv. Nutr. 2019, 11, 349-356. [CrossRef]

30. Subramaniam, M.; Chua, B.Y.; Abdin, E.; Pang, S.; Satghare, P.; Vaingankar, J.A.; Verma, S.; Ong, S.H.; Picco, L.; Chong, S.A. Prevalence and Correlates of Internet Gaming Problem among Internet Users: Results from an Internet Survey. Ann. Acad. Med. Singap. 2016, 45, 174-183.

31. Qin, K.; Zhang, F.; Chen, T.; Li, L.; Li, W.; Suo, X.; Lei, D.; Kemp, G.J.; Gong, Q. Shared gray matter alterations in individuals with diverse behavioral addictions: A voxel-wise meta-analysis. J. Behav. Addict. 2020, 9, 1-14. [CrossRef] [PubMed]

32. Yang, G.; Cao, J.; Li, Y.; Cheng, P.; Liu, B.; Hao, Z.; Yao, H.; Shi, D.; Peng, L.; Guo, L.; et al. Association Between Internet Addiction and the Risk of Musculoskeletal Pain in Chinese College Freshmen-A Cross-Sectional Study. Front. Psychol. 2019, 10, 1959. [CrossRef] [PubMed]

33. Dahl, D.; Bergmark, K.H. Persistence in Problematic Internet Use-A Systematic Review and Meta-Analysis. Front. Sociol. 2020, 5, 30. [CrossRef] 